\title{
Pemberdayaan Kelompok Masyarakat Desa Karang Anyar untuk Meningkatkan Pendapatan dalam Produksi Usaha Rengginang
}

\section{Empowerment of Karang Anyar Village Community Groups to Increase Revenue in Rengginang Business Production}

Ramsul Nababan, Jufri Darma, Kaerul Saleh \& Ali Nurman

Universitas Negeri Medan, Indonesia

Diterima: 17 Desember 2019 ; Disetujui: 05 Maret 2020 ; Dipublish: 09 Maret 2020

*Corresponding Email : ramsulnababan@gmail.com

\section{Abstrak}

Kegiatan Pengabdian kepada Masyarakat ini bertujuan untuk meningkatkan kualitas dalam manajemen pembukuan keuangan, kualitas pengemasan dan merek dagang Usaha Kecil Menengah (UKM) di Desa Karang Anyar. Permasalahan yang dihadapi oleh Mitra di sini yaitu; (1) pengelolaan keuangan masih belum tercatat secara terus menerus dan bersifat manual tanpa mempunyai catatan antara modal dan keuntungan, (2) pengemasan rengginang menggunakan plastik kiloan sehingga kemasan mudah sobek, dan kemasan tidak menarik serta belum memiliki merek dagang. Solusi yang ditawarkan di sini, Mitra diberikan pelatihan, pendidikan, pendampingan, sosialisai, dan penyerahan Teknologi Tepat Guna (TTG) mengenai permasalahan yang dihadapi oleh Mitra. Metode pelaksanaan program pengabdian akan dilakukan secara pendekatan secara bertahap, berkelanjutan, dan komprehensif melalui komunikasi secara langsung atau lewat alat komunikasi secara intensif dengan Mitra, sehingga pelaksanaan kegiatan dapat dilakukan secara terbimbing, dengan tujuan utama untuk meningkatkan perekonomian masyarakat dalam mengelolah Usaha Kecil Menengah (UKM) dengan usaha makanan rengginang.

Kata Kunci: Pemberdayaan Masyarakat, Desa Karang Anyar, Usaha rengginang

\begin{abstract}
Community Service Activities aims to improve the quality of financial bookkeeping management, the quality of packaging and trademarks for Small and Medium Enterprises (SMEs) in Karang Anyar Village. The problems faced by Partners here are; (1) financial management has not been recorded continuously and is manual without having a record between capital and profits, (2) rengginang packaging using kiloan plastic so that the packaging is easily torn, and the packaging is not attractive and does not yet have a trademark. The solution offered here, Partners are given training, education, assistance, socialization, and the delivery of Appropriate Technology (TTG) regarding the problems faced by Partners. The method of implementing the service program will be carried out in a gradual, sustainable and comprehensive approach through direct communication or through intensive communication tools with partners, so that the implementation of activities can be carried out in a guided manner, with the primary aim of improving the community's economy in managing Small and Medium Enterprises (SMEs) ) with Rengginang food business.
\end{abstract}

Keywords: Community Empowerment, Karang Anyar Village, Rengginang Business

How to cite: Nababan R, Darma J, Saleh K, \& Nurman A, (2020). Pemberdayaan Kelompok Masyarakat Desa Karang Anyar untuk Meningkatkan Pendapatan dalam Produksi Usaha Rengginang. Pelita Masyarakat: Jurnal Pengabdian Masyarakat 1(2): 76-82.

\section{PENDAHULUAN}

Desa Karang Anyar terletak di dalam wilayah Kecamatan Beringin Kabupaten Deli Serdang Provinsi Sumatera Utara yang berbatasan dengan; (1) sebelah utara berbatasan dengan Desa Beringin; (2) sebelah timur berbatasan dengan Desa Sidorejo II R; (3) 
sebelah selatan berbatasan dengan Desa Sidodadi Ramunia; (4) sebelah barat berbatasan dengan Bandara Kuala Namu. Luas Desa Karang Anyar adalah 463,9 HA dimana 100\% berupa daratan dengan ketingguian dari permukaan air laut 0-3 m dan dan 25\% dimanfaatkan sebagai pola tanam pada lahan pertanian yang ada di desa Karang Anyar Kecamatan Beringin.

Penduduk Desa Karang Anyar berjumlah 7.789 jiwa, yang terdiri dari laki-laki 3.863 jiwa, perempuan 3.962 jiwa, dan 1.834 KK, (Profil Desa Karang Anyar, 2018), yang berasal dari berbagai daerah yang berbeda-beda, penduduknya dominan berasal dari suku Melayu, Batak, Jawa, dan ditambah beberapa suku lainnya, memiliki tradisi-tradisi musyawarah/mufakat, gotong-royong dan kearifan lokal sudah dilakukan oleh masyarakat.

Berdasarkan jumlah penduduk dan KK yang ada di Desa Karang Anyar di atas, sebagian besar bermata pencaharian bertani/berkebun, buruh bangunan/tani, berdagang/wiraswasta, dan sebagian kecil sebagai Pegawai Negeri Sipil (PNS) dan pegawai/karyawan swasta. Beragamnya profesi penduduk yang ada di Desa Karang Anyar merupakan keanekaragaman kekayaan keahlian yang dimiliki oleh masyarakat Desa tersebut, dimana kepala Desa Karang Anyar sangat berkeinginan besar untuk “Mewujudkan Masyarakat Desa Karang Anyar yang Berkualitas dibidang berusaha dan mensejahterahkan masyarakat Desa Karang Anyar". Salah satu usaha pemerintah Desa untuk mewujudkan masyarakat yang sejahtera, yaitu dengan memberikan kebebasan bagi masyarakatnya untuk berwirausaha, hal ini tidak hanya bagi kaum bapak-bapak saja, namun kaum ibu-ibu juga bisa berwirausaha yang nantinya bisa membantu perekonomian yang lebih baik dalam sebuah keluarga.

Pemerintahan Desa Karang Anyar sangat antusias dalam mendukung memajukan industri rumah tangga dan kegiatan-kegiatan rumahan yang bersifat positif misalnya dalam berwirausaha, dengan adanya Usaha Kecil Menengah (UKM) rumahan, usaha rumahan ini bisa memanfaatkan hasil pertanian yang ada di Desa Karang Anyar, para pemilik usaha tidak susah lagi mencari bahan baku untuk usaha tersebut. Hal ini terlihat dengan adanya UKM yang mengelolah hasil pertanian masyarakat Desa Karang Anyar, yaitu memanfaatkan lahan pertanian dalam menanam beras ketan. UKM yang berada di Desa Karang Anyar adalah dengan mengolah beras ketan menjadi makanan rengginang. 
Adapun usaha rengginang di Desa Karang Anyar tersebut telah lama dikelola oleh masyarakat setempat sebagai penambah perekonomian keluarga.

UKM ini dalam setiap minggunya dapat memperoduksi makanan rengginang mentah sebanyak 25-50Kg, yang dikemas dalam plastik polos bening (plastik khusus untuk kiloan) ukuran $1 \mathrm{~kg}, 1 / 2 \mathrm{~kg}$, dan $1 / 4 \mathrm{~kg}$, ada juga rengginang yang sudah digoreng dengan dimasukkan ke dalam plastik polos (plastik tipis kiloan) kemudian dipeking dengan cara dipress secara manual untuk mengunci rengginang. Tidak jarang juga kemasan rengginang sering rusak dan bocor ketika berada di warung-warung tradisional atau ketika dalam pembungkusan produk, hal ini dikarenakan plastik yang digunakan adalah plastik untuk pengemasan tipis kiloan, tidak memakai plastik tebal yang khusus untuk makanan kering seperti rengginang.

Harga jual dari rengginang dibandrol dengan harga Rp. 5.000,- (lima ribu rupiah) sampai dengan Rp. 25.000,- (dua puluh lima ribu rupiah). Proses kegiatan mulai dari pengolahan bahan mentah, pembukuan keuangan, packing hasil produksi, sampai kepada penjualan dan pemasaran selama ini dilakukan oleh para usaha makanan rengginang secara manual, yaitu pembukuan keuangan masih sangat sederhana, bersifat kekeluargaan dan belum profesional, pengemasan menggunakan dengan plastik tipis kiloan kemudian dipress secara manual agar tidak masuk angin, merek dagang/branding (nama merek, slogan, komposisi, gambar ilustrasi, alamat, nomor hand phone (HP), dan hal-hal lain yang berhubungan dengan branding belum ada, dan penjualan belum dapat dipasarkan ke luar dari Desa Karang Anyar dan waralaba seperti minimarker dan hanya diletakkan di warung-warung tradisional, sekolah-sekolah sekitar Desa Karang Anyar dan pada saat acara-acara pesta perkawinan serta pada acara-acara keagamaan seperti Lebaran Idul Fitri.

Beberapa hambatan dan kendala yang dihadapi oleh UKM di Desa Karang Anyar, mulai dari pembukuan keuangan yang masih bersifat manual terkadang tidak tercatat, desain pengemasan, dan pemasaran rengginang. Hal ini yang membuat UKM di Desa Karang Anyar tidak berkembang dengan baik, namun hambatan dan kendala yang ada tersebut dapat diatasi dengan mendatangkan ahli untuk membenahi hambatan dan kelemahan-kelemahan dari masing-masing bidang, mulai dari manajemen pembukuan keuangan, desain kemasan produk yang lebih menarik, hingga kepada pemasaran produk makanan rengginang. 
Masyarakat yang mengelola kuliner rengginang sangat berharap adanya pendampingan dan pelatihan dalam pengembangan desain produk dan mengembangkan usaha produksi (pembuatan dan pengemasan) makanan rengginang berbasis manajemen. Sementara pengetahuan mereka tentang manajemna usaha yang baik masih sangat kurang. Sehingga perlu ada upaya bersama agar para ibu-ibu yang bekerja mengurus rumah tangga menjadi produktif untuk meningkatkan pendapat keluarganya.

\section{METODE PELAKSANAAN}

Berdasarkan permasalahan yang telah dikemukakan, maka dalam kegiatan PKM ini metode pelaksanaan yang digunakan adalah metode pemaparan dan diskusi, pelatihan, pendampingan, simulasi, observasi, wawancara, catatan lapangan, dan kerjasama. Berdasarkan metode tersebut untuk memecahkan masalah melalui beberapa tahapan persiapan. Tahap persiapan ini dilakukan beberapa kegiatan sebagai berikut: (a). sosialisasi program pengabdian kepada Mitra di Desa Karang Anyar Kecamatan Beringin Kabupaten Deli Serdang; (b). melaksanakan observasi dan mewawancarai terhadap Mitra serta melakukan diskusi untuk mengetahui situasi dan permasalahan serta pemecahan masalah yang dihadapi oleh Mitra; (c). penentuan jadwal kegiatan; (d). adanya saling berkomitmen antara pengabdi dengan Mitra; (e). Melaksanakan kegiatan Focus Group Discussion (FGD) dengan mitra; (f). melakukan pendidikan, pelatihan, dan pendampingan tentang pentingnya pembuatan desain pengemasan dan merek dagang; (g). melakukan pendidikan, pelatihan, dan pendampingan tentang bagaimana membuat laporan pembukuan secara sederhana; dan (h) mempersiapkan sarana dan prasarana untuk mendukung terlaksananya kegiatan Pengabdian Kepada Masyarakat.

Untuk mencapai tahapan diatas maka partisipasi mitra dan pelaksanaan program yang akan dilakukan tim pengabdian pada kelompok mitra, antara lain:

1. Tahap Awal

a. Mengevaluasi pemahaman mitra tentang berwirausaha dan manajemen usaha.

b. Mengevaluasi pemahaman mitra tentang sistem pemasaran menggunakan IT.

c. Mengevaluasi pemahaman mitra tentang sistem pengelolaan keuangan yang baik.

2. Tahap Pelaksanaan

a. Mengevaluasi pemahaman mitra terhadap proses berwirausaha dan manajemen usaha.

b. Mengevaluasi pengawasan mitra dalam pelaksanaan pemasaran dengan menggunakan IT.

c. Melakukan pengawasan mitra dalam pengelolaan keuangan yang baik.

3. Tahap Akhir 
Ramsul Nababan, Jufri Darma, Kaerul Saleh \& Ali Nurman, Pemberdayaan Kelompok Masyarakat Desa

Mengukur indikator peningkatan pendapatan kelompok UKM Rengginang Karang Anyar. Bila mengalami keberhasilan akan dilaksanakan dengan kegiatan pengembangan keberlanjutan.

\section{HASIL DAN PEMBAHASAN}

Pelaksanaan kegiatan yang dilakukan dalam Pengabdian Kepada Masyarakat ini, yakni sebagai berikut: a). Melakukan Focus Group Discussion (FGD) dengan mitra; b). Melakukan kegiatan pelatihan, pendampingan, pendidikan, dan sosialisasi tentang pembukuan keuangan, pengemasan, dan merek dagang; dan c). Serah terima alat Tehnologi Tepat Guna (TTG) serta serah terima kemasan hard copy dan soft copy merek dagang Rengginang Deli.

Metode pendekatan yang dilakukan guna menyelesaikan persoalan mitra, sebagai berikut: observasi lapangan ke lokasi mitra, berkomunikasi dengan mitra, mengelompokan masalahan mitra, mencari problem solving, penentuan lokasi kegiatan (dalam hal ini mitra berperan untuk memfasilitasi tempat kegiatan), $F G D$, pelatihan, pendampingan, pendidikan, sosialisai, serah terima model kemasan baru, serah terima hard copy dan soft copy model merek dagang baru, pendampingan akhir, dan evaluasi kegiatan.

Selain metode pendekatan diatas sangat diperlukan beberapa kepakaran yang dibutuhkan dalam pencapaian hasil kegiatan yang maksimal sebagai berikut: 1). Ahli Pemberdayaan Kemasyarakatan. Pemberdayaan masyarakat merupakan proses pembangunan sumber daya manusia/masyarakat itu sendiri dalam bentuk penggalian kemampuan pribadi, kreativitas kompetensi dan daya pikir yang lebih baik dari waktu sebelumnya untuk memperbaiki situasi dan kondisi diri sendiri. Pemberdayaan masyarakat hanya bisa terjadi apabila masyarakat itu sendiri ikut berpartisipasi. Salah satu tujuan pemberdayaan masyarakat adalah untuk menumbuhkan ketrampilan yang mandiri secara individu di dalam masyarakat. Oleh karena itu, agar kelompok UKM Rengginang Karang Anyar yang tidak produktif di bidang ekonomi agar dapat membantu meningkatkan pendapatan keluarganya diperlukan pakar bidang pemberdayaan masyarakat; 2). Ahli Manajemen Usaha, Pembukuan Keuangan dan Pemasaran. Pengelolaan manajemen usaha dibutuhkan dalam konteks internal sebuah perusahaan, agar perusahaan memiliki arah dalam menjalankan usaha terukur dan terencana dengan baik. Dalam bisnis yang relatif baru, sangat diperlukan kreatifitas, dan perencanaan usaha yang semakin dibutuhkan. Oleh karena itu dalam kegiatan pendidikan, pelatihan, dan pendampingan yang akan dilakukan pada kelompok UKM Rengginang Karang Anyar 
tentang penyusunan laporan keuangan, maka dengan itu perlu didatangkan pakar dalam bidang ekonomi terkhusus perekonomian usaha mikro kecil menengah dalam peningkatan penerapan ipteks di masyarakat, IT dan manajemen usaha yang baik, dan pembukuan sederhana untuk transaksi jual beli dalam menghitung pendapatan terhadap produksi usaha rengginang sehinga usaha yang akan dijalankan oleh kelompok UKM Rengginang Karang Anyar memiliki arah dalam usaha terencana dan terukur dengan baik serta mahir dalam bidang ekonomi pemasaran online; dan 3). Ahli Desain Kemasan dan Desain Produk. Dalam upaya pembuatan kreatif produk yang baik pada kelompok UKM Rengginang di Desa Karang Anyar perlu adanya pelatihan, pendampingan dan sosialisasi pembuatan desain kemasan produk rengginang yang menarik sosialisasi yang langsung mendatangkan pakar Seni Rupa dan Desain. Kemasan yang dibuat tersebut dapat bertahan lama dan tidak cepat masuk angin sehingga rengginang yang diproduksi dapat bertahan lama.

\section{SIMPULAN}

Kegiatan Pengabdian kepada Masyarakat di Desa Karang Anyar bertujuan untuk pemberdayaan kelompok masyarakat Desa Karang Anyar untuk meningkatkan pendapatan dalam produksi usaha rengginang. Hambatan dan permasalahan yang dihadapi oleh mitra, yaitu: 1. Pengelolaaan dalam keuangan yang selama ini dilakukan oleh mitra belum maksimal sehingga antara modal dan keuntungan tidak terlihat dan tidak jarang modal dan keuntungan digunakan untuk keperluan yang lain; 2. Desain kemasan rengginang selama ini menggunakan plastik yang tipis sehingga kemasan mudah bocor dan sobek; 3. Desain kemasan belum mempunyai merek dagang; dan 4. Penjualan rengginang masih bersifat tradisional dengan cara menitipkan rengginang di kantin sekolah, warung-warung maupun di pasar tradisional sekitar Desa Karang Anyar.

Untuk menyelesaikan permasalahan dan hambatan yang dihadapi oleh mitra maka solusi yang ditawarkan adalah Mitra diberikan pendidikan, pelatihan, sosialisasi, pendampingan, dan penyerahan Teknologi Tepag Guna (TTG). Untuk mencapai solusi tersebut maka kepada mitra diberikan target khusus yang diberikan kepada mitra melalui program pengabdian kepada masyarakat ini adalah sebagai berikut: (1) Adanya panduan pembukuan keuangan sederhana yang dirancang untuk mengetahui dan menghitung keuangan usaha; (2) desain kemasan yang semakin menarik dengan 
menggunakan plastik yang tebal agar tidak mudah sobek dan bocor sehingga rengginang dapat beratahan lama; (3) kemasan rengginang sudah memiliki merek dagang; dan (4) penjualan rengginang sudah dapat dipasarkan diluar Desa Karang Anyar. Adapun yang menjadi luaran yang dihasilkan dari kegiatan Pengabdian Kepada Masyarakat ini sebagai berikut: (1) Adanya panduan pembukuan keuangan sederhana; (2) plastik desain kemasan sudah memakai yang tebal dan semakin menarik untuk makanan kering seperti rengginang; (3) mempunyai merek dagang (soft copy) yang dicetak di atas kertas stiker, dan (5) tersedianya alat perekat kemasan plastik (sealer). Sedangkan metode yang digunakan dalam pelaksanaan program pengabdian kepada masyarakat dilakukan secara berkesinambungan dan komprehensif sehingga proses kegiatan yang dilakukan dapat terlaksana dengan komunikasi secara langsung dengan sehingga kegiatan ini dapat dilakukan secara terarah dan terbimbing agar mitra dapat meningkatkan kesejahteraan keluarga melalui usaha rengginang.

\section{DAFTAR PUSTAKA}

http://it4ukm.blogspot.com/2013/07/tiga-tips-cara-mengelola-usaha-kecil.html. Tiga Tips Cara Mengelola Usaha Kecil Menengah Yang Benar. Tanggal akses 10 Oktober 2019. http://triwitono.staff.ugm.ac.id/index.php?option=com_content\&view=
pembuatanrengginang\&catid=28:proses pengolahan\&Itemid=53. Download 15 Oktober 2019. Tanggal akses 15 Mei 2019

http://triwitono.staff.ugm.ac.id/index.php?option=com_content\&view= article\&id=95:prosespembuatanrengginang\&catid=28:proses pengolahan\&Itemid=53. Download 17 Oktober 2019. Diakses tanggal 17 Oktober 2019

Kotler dan Keller. (2009). Manajemen Pemasaran Jilid I. Edisi ke 13. Jakarta: Erlangga

Lauw, A. \& Kimber, M. 2007. The power of Packaging, The customer Equity Company.

Peter. Paul J, Jerry C. Olson. (2011). Perilaku Konsumen \& Strategi Pemasaran Ed.9, Buku 2.Salemba Empat. Jakarta.

Susilo, Y.S. (2010). Strategi Meningkatkan Daya Saing UMKM Dalam Menghadapi Implementasi Cafta Dan Mea. Buletin Ekonomi Vol. 8, No. 2, Agustus 2010 hal 70-170. Diakses dari http://www.kadinindonesia.or.id pada tanggal 18 September 2019.

Trimurti, (2010). Model Pelatihan Kewirausahaan Berbasis Penerapan Teknologi Tenun Ikat www.sumutpos.com. 2012. Wali Kota Medan: Jadikan 2013 Tahun Kebangkitan UMKM.Sumut Pos. Medan. Zimmerer, S, (2010). Kewirausahaan dan Manajemen Usaha kecil Edisi ke-5. Salemba Empat. Jakarta. 